Jurnal ELTIKOM, Vol. 1 No.1, Juni 2017, Hal 11-22 ISSN 2598-3245 (Print), ISSN 2598-3288 (Online)

Tersedia Online di http://eltikom.poliban.ac.id

\title{
SISTEM INFORMASI PENJURUSAN DAN PENERIMAAN PESERTA DIDIK BARU MENGGUNAKAN METODE WEIGHTED PRODUCT
}

\author{
Reza Fauzan 1), Rahimi Fitri ${ }^{2)}$,Muhammad Fadliansyah ${ }^{3)}$ \\ ${ }^{1,2,3)}$ Politeknik Negeri Banjarmasin \\ e-mail: reza.fauzan@poliban.ac.id ${ }^{1)}$, rahimi_fitri@poliban.com²), muhammadfadliansyah199@gmail.com ${ }^{3)}$
}

\begin{abstract}
MAN 2 Model Banjarmasin is an Islamic based school, based on the Regulation of the Minister of Education and Culture of the Republic of Indonesia Number 64 Year 2014 concerning specialization in secondary / high school education to specialize in the acceptance of new learners. In this study, the author discusses the information system penjurusan and acceptance of new learners using one branch of science decision support system based on artificial intelligence that is Weighted Product method in MAN 2 Model web based Banjarmasin. In the implementation of program code using PHP programming language with codeigniter framework (CI) and MySQL database. This selection is based on several criteria set by the school MAN 2 Model Banjarmasin. The results of this study produce programs that run well. The initial weight to calculate the stipulation of the student data is $27 \%$ report rate, 33\% for academic test, and 20\% for psychological test and BTA. The weight to perform the calculation of student acceptance data is the value of the report card and the value of psychotest by $20 \%$, the value of academic tests and BTA by $30 \%$ as the calculation data will be processed to produce ranking majors and establish the status of students received since the participants register themselves as prospective learners in MAN 2 Model Banjarmasin.
\end{abstract}

Keyword: Alignment, Acceptance, Student, Weighted Product Method.

\begin{abstract}
ABSTRAK
MAN 2 Model Banjarmasin adalah sekolah berbasis Islam, berdasarkan Peraturan Menteri Pendidikan dan Kebudayaan Republik Indonesia Nomor 64 Tahun 2014 tentang peminatan pada pendidikan menengah SMA/MA untuk melakukan peminatan saat penerimaan peserta didik baru. Dalam penelitian ini, penulis membahas tentang sistem informasi penjurusan dan penerimaan peserta didik baru menggunakan salah satu cabang ilmu sistem pendukung keputusan berbasis kecerdasan buatan yaitu Metode Weighted Product di MAN 2 Model Banjarmasin berbasis web. Dalam implementasi code program menggunakan bahasa pemprograman PHP dengan framework codeigniter (CI) serta database MySQL. Penyeleksian ini berdasarkan atas beberapa kriteria yang ditetapkan oleh pihak sekolah MAN 2 Model Banjarmasin. Hasil penelitian ini menghasilkan program yang berjalan dengan baik. Bobot awal untuk melakukan perhitungan ketetapan penjurusan data siswa ini berupa nilai rapor sebesar $27 \%$, nilai tes akademik sebesar 33\%, dan nilai psikotes dan BTA sebesar 20\%. Bobot untuk melakukan perhitungan penerimaan data siswa ini berupa nilai rapor dan nilai psikotes sebesar $20 \%$, nilai tes akademik dan BTA sebesar 30\% sebagai perhitungan data yang akan diproses untuk menghasilkan perangkingan penjurusan dan menetapkan status siswa yang diterima sejak peserta mendaftarkan dirinya sebagai calon peserta didik di MAN 2 Model Banjarmasin.
\end{abstract}

Kata Kunci : Penjurusan, Penerimaan, Peserta Didik, Metode Weighted Product.

\section{Pendahuluan}

$\mathrm{M}$ AN 2 Model Banjarmasin adalah sekolah tingkat menengah atas yang berciri khas Agama Islam di bawah Kementerian Agama. Dalam penerimaan ini MAN 2 Model Banjarmasin melaksanakan secara tersendiri melalui jalur seleksi tiap tahunnya. Peserta didik baru adalah peserta didik yang mendaftarkan dirinya dan lulus seleksi masuk pada Madrasah [1]. Sesuai dengan peraturan Menteri Pendidikan dan Kebudayaan Republik Indonesia Nomor 64 Tahun 2014 tentang Peminatan pada Pendidikan Menengah pasal 4 ayat (1) dan (2) yang menyatakan pemilihan dilakukan 
sejak peserta didik mendaftar ke SMA/MA sesuai dengan minat dan didasarkan pada nilai rapor, nilai Ujian Nasional, dan rekomendasi guru Bimbingan di SMP/MTs Sederajat [2]. Jurusan yang ada di MAN 2 Model Banjarmasin ada tiga yaitu MIA (Matematika dan Ilmu Alam) dengan konsentrasi IPA, IIS (Ilmu-ilmu Sosial) dengan konsentrasi IPS, dan IIK (Ilmu-Ilmu Agama) dengan konsentrasi Agama, berhubungan dengan sistem penjurusan yang masih manual, maka dilakukan observasi penelitian untuk mengembangkan sistem tersebut menjadi sistem komputerisasi berbasis kecerdasan buatan. Metode Weighted Product adalah salah satu sistem pendukung keputusan berbasis kecerdasan buatan dengan pembuatan keputusan atribut berganda, karena dalam penentuan penjurusan ini memiliki banyak kriteria untuk mempertimbangkan pilihan jurusan terbaik bagi calon peserta didik yang ingin mendaftar di MAN 2 Model Banjarmasin.

Menurut Bonczek et al. menunjukkan sebuah Sistem Pendukung Keputusan (SPK) sebagai sebuah sistem berbasis komputer yang terdiri atas tiga komponen yang saling berinteraksi antara lain sistem bahasa (mekanisme untuk memberikan komunikasi antara penguna dan komponen sistem keputusan lainnya), sistem pengetahuan (respositori pengetahuan domain masalah yang ada pada sistem pendukung keputusan atau sebagai data atau prosedur), dan sebuah sistem pemprosesan masalah (hubungan antara dua komponen, terdiri satu atau lebih dari kapabilitas manipulasi masalah umum yang diperlukan dalam pengambilan keputusan). Konsep tersebut penting untuk memahami hubungan antara SPK dan pengetahuan [3].

Salah satu metode yang diambil dalam Sistem Pendukung Keputusan (SPK) jurusan ini yaitu menggunakan metode weighted product, Metode Weighted Product adalah salah satu dari metode yang bisa menyelesaikan masalah dalam pembuatan keputusan atribut berganda (Multi Attribute Decision Making-MADM). Menurut Hwang dan Masud mendefiniskan bahwa MADM merupakan bagian bidang pembuatan keputusan dengan banyak kriteria (multiple criteria decision) dengan tujuan berganda (Multiple Object Decision Making-MODM) [4].

Menurut Sianturi Ingot Seen menerangkan bahwa Metode Weighted Product (WP) merupakan salah satu metode yang digunakan untuk menyeleksi masalah. Metode ini menggunakan perkalian untuk menghubungkan nilai atribut (kriteria), dimana nilai setiap atribut harus dipangkatkan dulu dengan bobot atribut (kriteria) yang bersangkutan. Bobot untuk atribut bertujuan untuk sebagai pangkat positif dalam proses perkalian antar atribut sementara pangkat negatif untuk atribut biaya [5].

Dalam pengembangan sistem ini dilakukan pada sistem penerimaan peserta didik baru yang ditambahkan dengan sistem pendukung keputusan penjurusan di MAN 2 Model Banjarmasin dengan menggunakan metode weighted product dan diharapkan mampu menangani permasalahan untuk melakukan penjurusan dan penerimaan peserta didik baru sejak pendaftar mendaftarkan dirinya di MAN 2 Model Banjarmasin.

Sesuai dengan latar belakang, maka tujuan dalam penelitian ini adalah untuk merancang dan membangun sistem informasi penjurusan dan penerimaan peserta didik baru menggunakan metode weighted product di MAN 2 Model Banjarmasin berbasis Web.

\section{METODOLOGI PENELITIAN}

\subsection{Rancangan Penelitian}

Adapun alur sistem penjurusan dan penerimaan di MAN 2 Model Banjarmasin, sebagai berikut.

a. Alur Sistem Pendaftaran

Dalam alur ini calon Peserta didik bisa langsung mendaftarkan dirinya pada form yang sudah disediakan pada sistem yang dirancang tanpa login sebelumnya, dan mengupload berkas pendukung ke email sekolah yang telah disediakan pihak sekolah, setelah pendaftaran selesai maka Pendaftar langsung dapat mencetak kartu pendaftaran.

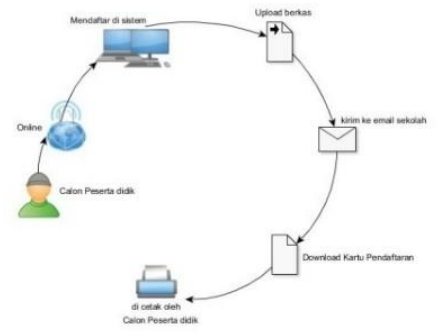


b. Alur Sistem Penjurusan

Dalam alur ini, setelah calon Peserta mengikuti tes seleksi di Sekolah bersangkutan, panitia akan memberikan kepada Admin untuk memasukkan nilai tes para calon Peserta di sistem yang dirancang, kemudian semua nilai nantinya akan masuk ke dalam proses perhitungan weighted product untuk menentukan jurusan yang terbaik bagi calon Peserta tersebut, setelah hasil saran penjurusan tampil di sistem maka Admin akan menentukan jurusan yang terbaik tersebut.

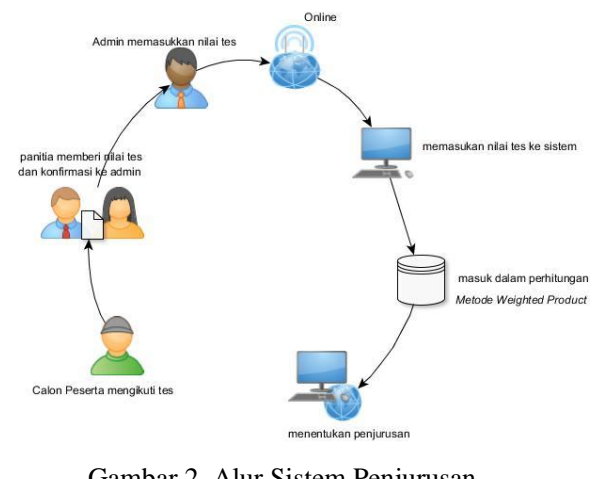

Gambar 2. Alur Sistem Penjurusan

c. Alur Sistem Penyeleksian

Dalam alur ini ,setelah proses penjurusan dilakukan, maka Admin akan masuk ke tahapan seleksi diterima atau tidaknya calon Peserta berdasarkan jumlah kuota yang telah ditentukan sebelumnya, di Sistem ini menggunakan sistem gugur dalam penyeleksiannya yaitu dengan diterima sesuai daya tampung sekolah. Setelah selesai proses penyeleksian maka Admin akan membuka form hasil seleksi di bagian frontend website, disini calon Peserta akan dapat secara langsung melihat hasil seleksinya dengan memasukkan terlebih dahulu nomor pendaftaran mereka masing-masing, nantinya pada sistem akan menampilkan kata diterima, cadangan, atau ditolak calon Peserta bersangkutan.

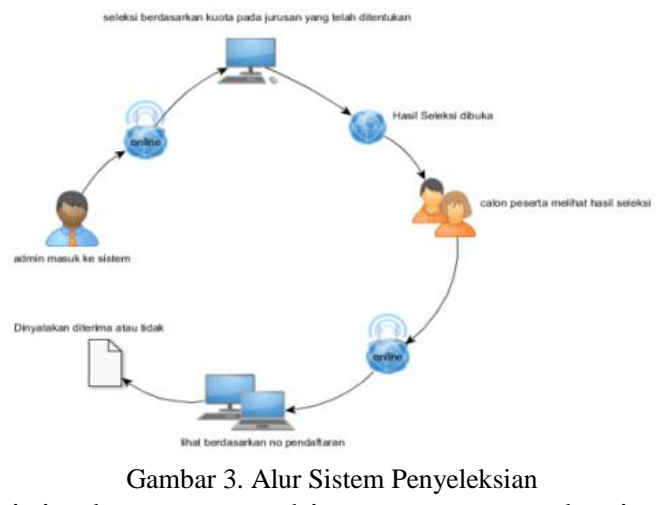

Dalam perancangan sistem ini ada proses perhitungan yang terbagi menjadi dua yaitu perhitungan untuk penjurusan yaitu dengan menggunakan metode weighted product dan perhitungan untuk penerimaan secara sederhana, sebagai berikut :

\subsection{Perhitungan Penjurusan dengan Metode Weighted Product}

Adapun tahapan dalam perhitungan menggunakan metode weighted product ini adalah sebagai berikut :

- Menentukan terlebih dahulu nilai bobot nya.

\begin{tabular}{c} 
TABEL 1 \\
\multicolumn{1}{c|}{ NILAI BOBOT } \\
\begin{tabular}{|c|c|}
\hline Bobot & Keterangan \\
\hline 5 & Sangat baik \\
\hline 4 & Baik \\
\hline 3 & Cukup \\
\hline 2 & Buruk \\
\hline 1 & Sangat buruk \\
\hline
\end{tabular}
\end{tabular}

- Menentukan kriteria penilaian bobot awal

Dalam penjurusan ini, ada beberapa kriteria yang dinilai, yang mana untuk nilai tes akademik lebih 
prioritas dari nilai rapor, nilai BTA dan psikotes.

TABEL 2

KRITERIA MENENTUKAN PENILAIAN (BOBOT AWAL)
\begin{tabular}{|l|c|}
\hline \multicolumn{1}{|c|}{ Kriteria } & Bobot \\
\hline Nilai rapor (C1) & 4 \\
\hline Nilai tes (C2) & 5 \\
\hline Nilai tes Psikotes (C3) & 3 \\
\hline Nilai BTA (C4) & 3 \\
\hline
\end{tabular}

- Menghitung perbaikan bobot awal

Setelah menentukan bobot awal, maka harus diperbaiki terlebih dahulu pembobotan tersebut yaitu nilai rapor (C1) sebesar 4, nilai tes (C2) sebesar 5, nilai tes psikotes (C3) sebesar 3, dan nilai BTA (C4) sebesar 3. Adapun rumus dari perbaikan pembobotan awal ini adalah sebagai berikut :

Keterangan :

$$
w_{j}=\frac{w}{\sum w}
$$

$\mathrm{Wj}$ = pangkat bernilai positif untuk atribut keuntungan dan bernilai negatif untuk atribut biaya.

$\mathrm{W}=$ menyatakan bobot kriteria

Jadi, hasilnya perbaikan bobotnya seperti dibawah ini

$$
\begin{aligned}
& w 1=\frac{4}{4+5+3+3}=\frac{4}{15}=0,27=27 \% \\
& w 2=\frac{5}{4+5+3+3}=\frac{5}{15}=0,33=33 \% \\
& w 3=\frac{3}{4+5+3+3}=\frac{3}{15}=0,20=20 \% \\
& w 4=\frac{3}{4+5+3+3}=\frac{3}{15}=0,20=20 \%
\end{aligned}
$$

- Menentukan penilaian kriteria dari beberapa jurusan

\begin{tabular}{|c|c|c|}
\hline \multicolumn{3}{|c|}{ KRITERIA PENJURUSAN MIA (IPA) } \\
\hline Alternatif & Kriteria & Bobot \\
\hline \multirow{4}{*}{$\begin{array}{c}\text { MIA } \\
\text { (IPA) }\end{array}$} & Nilai rapor IPA(C1) & $27 \%$ \\
\hline & Nilai tes IPA(C2) & $33 \%$ \\
\hline & Nilai Psikotes (C3) & $20 \%$ \\
\hline & Nilai tes BTA (C4) & $20 \%$ \\
\hline \multicolumn{2}{|r|}{ Total } & $100 \%$ \\
\hline
\end{tabular}

Setelah selesai melakukan perhitungan perbaikan bobot awal, maka hasilnya tersebut dibagikan menjadi beberapa penilaian kriteria jurusan, yaitu untuk jurusan alternatif MIA, jurusan alternatif IIS, dan jurusan alternatif IIK.

TABEL 3

TABEL 4

KRITERIA PENJURUSAN IIS (IPS)

\begin{tabular}{|c|l|c|}
\hline \multirow{2}{*}{ Alternatif } & \multicolumn{1}{|c|}{ Kriteria } & Bobot \\
\hline \multirow{3}{*}{$\begin{array}{c}\text { IIS } \\
\text { (IPS) }\end{array}$} & Nilai rapor IPS(C1) & $27 \%$ \\
\cline { 2 - 3 } & Nilai tes IPS(C2) & $33 \%$ \\
\cline { 2 - 3 } & Nilai Psikotes (C3) & $20 \%$ \\
\cline { 2 - 3 } & Nilai tes BTA (C4) & $20 \%$ \\
\hline \multicolumn{2}{|c|}{ Total } & $100 \%$ \\
\hline
\end{tabular}

TABEL 5

KRITERIA PENJURUSAN IIK (AgAmA)

\begin{tabular}{|c|l|l|}
\hline \multicolumn{1}{|c|}{ Alternatif } & \multicolumn{1}{|c|}{ Kriteria } & Bobot \\
\hline \multirow{4}{*}{$\begin{array}{c}\text { IIK } \\
\text { (AGAMA) }\end{array}$} & Nilai rapor Agama (C1) & $27 \%$ \\
\cline { 2 - 3 } & Nilai tes Agama (C2) & $33 \%$ \\
\cline { 2 - 3 } & Nilai Psikotes (C3) & $20 \%$ \\
\cline { 2 - 3 } & Nilai tes BTA (C4) & $20 \%$ \\
\hline \multicolumn{2}{|c|}{ Total } & $100 \%$ \\
\hline
\end{tabular}


- Perhitungan mencari hasil nilai penjurusan alternatif

Adapun rumus dalam mencari perhitungan hasil nilai alternatif dengan menggunakan metode weighted product adalah sebagai berikut :

$$
S_{i}=\prod_{j=1}^{n}=x_{i j}{ }^{w_{j}}
$$

Keterangan :

dengan $\mathrm{i}=1,2, \ldots, \mathrm{m}$, dimana :

$\prod$ (n-ary product)

$\mathrm{S}$ menyatakan preferensi alternatif,

$\mathrm{x}$ menyatakan nilai kriteria,

w menyatakan bobot kriteria,

n menyatakan banyaknya kriteria.

wj adalah pangkat bernilai positif untuk atribut keuntungan dan bernilai negatif untuk atribut biaya.

Jadi, diumpakan ada 4 orang pendaftar yang mendaftar di MAN 2 Model Banjarmasin dan memilih jurusan yaitu si $\mathrm{A}$, si $\mathrm{B}$, si $\mathrm{C}$, dan si $\mathrm{D}$. untuk penjurusan ini, yang mana prioritas penentuan antara pertimbangan yang akan disarankan sistem dan pada pilihan pertama. Adapun peminatan sebagai berikut.

TABEL 6
PEMINATAN
\begin{tabular}{|l|l|l|l|}
\hline Nama & Pilihan Pertama & Pilihan Kedua & Pilihan Ketiga \\
\hline Si A & IPA (MIA) & IPS (IIS) & Agama (IIK) \\
\hline Si B & Agama (IIK) & IPA (MIA) & IPS (IIS) \\
\hline Si C & IPS (IIS) & Agama (IIK) & IPA (MIA) \\
\hline Si D & IPA (MIA) & IPS (IIS) & Agama (IIK) \\
\hline
\end{tabular}

Kemudian dimasukan nilai-nilai berupa C1 (nilai rapor), C2 (nilai tes akademik), C3 (psikotes), dan C4 (BTA) pada masing-masing kriteria penilaian jurusan alternatif tersebut.

TABEL 7

INPUT NILAI PENJURUSAN MIA (IPA)

\begin{tabular}{|c|c|l|l|l|l|}
\hline \multirow{2}{*}{ No } & \multirow{2}{*}{ Nama } & \multicolumn{4}{|c|}{ Jurusan MIA (IPA) } \\
\cline { 3 - 6 } & & $\mathrm{C} 1$ & $\mathrm{C} 2$ & $\mathrm{C} 3$ & $\mathrm{C} 4$ \\
\hline 1 & $\mathrm{Si} \mathrm{A}$ & 80 & 80 & 77 & 67 \\
\hline 2 & $\mathrm{Si} \mathrm{B}$ & 87 & 78 & 87 & 77 \\
\hline 3 & $\mathrm{Si} \mathrm{C}$ & 77 & 76 & 76 & 68 \\
\hline 4 & $\mathrm{Si} \mathrm{D}$ & 78 & 77 & 75 & 78 \\
\hline
\end{tabular}

TABEL 8

INPUT NILAI PENJURUSAN IIS (IPS)

\begin{tabular}{|c|c|l|l|l|l|}
\hline \multirow{2}{*}{ No } & \multirow{2}{*}{ Nama } & \multicolumn{4}{|c|}{ Jurusan IIS (IPS) } \\
\cline { 3 - 6 } & & C1 & C2 & C3 & C4 \\
\hline 1 & Si A & 77 & 80 & 77 & 67 \\
\hline 2 & Si B & 87 & 80 & 87 & 77 \\
\hline 3 & Si C & 76 & 80 & 76 & 68 \\
\hline 4 & Si D & 76 & 80 & 75 & 78 \\
\hline
\end{tabular}

TABEL 9

INPUT NILAI PENJURUSAN IIK (AGAMA)

\begin{tabular}{|c|c|l|l|l|l|}
\multicolumn{7}{c}{ INPUT NILAI PENJURUSAN IIK (AGAMA) } \\
\hline \multirow{2}{*}{ No } & \multirow{2}{*}{ Nama } & \multicolumn{5}{|c|}{ Jurusan IIK (AGAMA) } \\
\cline { 3 - 6 } & & C1 & C2 & C 3 & C4 \\
\hline 1 & Si A & 78 & 80 & 77 & 67 \\
\hline 2 & Si B & 87 & 80 & 87 & 77 \\
\hline 3 & Si C & 65 & 88 & 76 & 68 \\
\hline 4 & Si D & 89 & 85 & 75 & 78 \\
\hline
\end{tabular}

Setelah itu, masuk ke proses perhitungan untuk mencari hasil penjurusan alternatif dengan rumus yang telah dipaparkan sebelumnya, yang mana hasilnya sebagai berikut:

- Untuk penjurusan MIA (IPA)

Dalam proses perhitungan nilai untuk alternatif Si penjurusan MIA (IPA) adalah sebagai berikut : 
Smia Si A $=\left(\left(80^{\wedge} 0,27\right)^{*}\left(80^{\wedge} 0,33\right)^{*}\left(77^{\wedge} 0,20\right)^{*}\left(67^{\wedge} 0,20\right)\right)=76,624$

Smia Si B $=\left(\left(87^{\wedge} 0,27\right)^{*}\left(78^{\wedge} 0,33\right)^{*}\left(87^{\wedge} 0,20\right)^{*}\left(77^{\wedge} 0,20\right)\right)=81,896$

Smia Si C $=\left(\left(77^{\wedge} 0,27\right) *\left(76^{\wedge} 0,33\right)^{*}\left(76^{\wedge} 0,20\right)^{*}\left(68^{\wedge} 0,20\right)\right)=74,591$

Smia Si D $=\left(\left(78^{\wedge} 0,27\right)^{*}\left(77^{\wedge} 0,33\right) *\left(75^{\wedge} 0,20\right) *\left(78^{\wedge} 0,20\right)\right)=77,062$

- Untuk penjurusan IIS (IPS)

Dalam proses perhitungan nilai untuk alternatif Si penjurusan IIS (IPS) adalah sebagai berikut :

Siis Si A $=\left(\left(77^{\wedge} 0,27\right)^{*}\left(80^{\wedge} 0,33\right)^{*}\left(77^{\wedge} 0,20\right)^{*}\left(67^{\wedge} 0,20\right)\right)=75,838$

Siis Si B $=\left(\left(87^{\wedge} 0,27\right)^{*}\left(80^{\wedge} 0,33\right)^{*}\left(87^{\wedge} 0,20\right)^{*}\left(77^{\wedge} 0,20\right)\right)=82,583$

Siis Si C $=\left(\left(76^{\wedge} 0,27\right)^{*}\left(80^{\wedge} 0,33\right) *\left(76^{\wedge} 0,20\right)^{*}\left(68^{\wedge} 0,20\right)\right)=75,597$

Siis Si $\mathrm{D}=\left(\left(76^{\wedge} 0,27\right)^{*}\left(80^{\wedge} 0,33\right)^{*}\left(75^{\wedge} 0,20\right)^{*}\left(78^{\wedge} 0,20\right)\right)=77,494$

- Untuk penjurusan IIK (Agama)

Dalam proses perhitungan nilai untuk alternatif Si penjurusan IIK (Agama) adalah sebagai berikut.

Siik Si A $=\left(\left(78^{\wedge} 0,27\right)^{*}\left(80^{\wedge} 0,33\right) *\left(77^{\wedge} 0,20\right)^{*}\left(67^{\wedge} 0,20\right)\right)=76,102$

Siik Si B $=\left(\left(87^{\wedge} 0,27\right) *\left(80^{\wedge} 0,33\right) *\left(87^{\wedge} 0,20\right)^{*}\left(77^{\wedge} 0,20\right)\right)=82,583$

Siik Si C $=\left(\left(65^{\wedge} 0,27\right)^{*}\left(88^{\wedge} 0,33\right)^{*}\left(76^{\wedge} 0,20\right)^{*}\left(68^{\wedge} 0,20\right)\right)=74,788$

Siik Si D $=\left(\left(89^{\wedge} 0,27\right) *\left(85^{\wedge} 0,33\right) *\left(75^{\wedge} 0,20\right)^{*}\left(78^{\wedge} 0,20\right)\right)=82,504$

\subsubsection{Perhitungan mencari hasil nilai penjurusan terbaik}

Adapun rumus dalam mencari perhitungan hasil nilai terbaik dengan menggunakan metode weighted product adalah sebagai berikut:

$$
V_{i}=\frac{\prod_{j=1}^{n} X_{i j}{ }^{w_{j}}}{\prod_{j=1}^{n}\left(X_{j}\right)^{w_{j}}}
$$

Dimana :

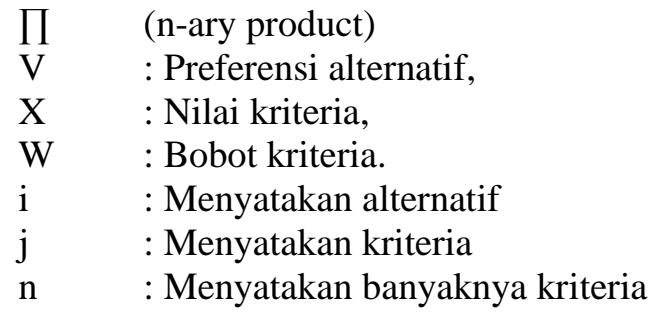

Setelah mendapatkan hasil perhitungan penjurusan alternatif, maka dilanjutkan dengan perhitungan untuk mencari hasil dari penjurusan terbaik, yang nantinya dapat mempertimbangkan dan menentukan penjurusan yang terbaik dari ketiga penjurusan yang ditentukan sebelumnya bagi pendaftar di MAN 2 Model Banjarmasin. Adapun perhitungannya sebagai berikut :

$$
=\frac{\text { nilai jurusan alternatif }}{\text { jumlah total nilai jurusan alternatif }}
$$

- Hasil si A

Proses Perhitungan menentukan jurusan terbaik si A adalah sebagai berikut :

$$
\begin{aligned}
& \text { Vmia Si } A=\frac{76,624}{76,624+75,838+76,102}=0,3352 \\
& \text { Viis Si } A=\frac{75,838}{76,624+75,838+76,102}=0,3318 \\
& \text { Viik Si } A=\frac{76,102}{76,624+75,838+76,102}=0,3330
\end{aligned}
$$

Maka Si A masuk dijurusan MIA (Matematika dan Ilmu Alam) atau IPA karena pilihan pertama adalah MIA. 
- Hasil si B

Proses Perhitungan menentukan jurusan terbaik si B adalah sebagai berikut :

Vmia Si B $=\frac{81,896}{81,896+82,583+82,583}=0,3315$

Viis Si B $=\frac{81,583}{81,896+82,583+82,583}=0,3343$

Viik Si B $=\frac{81,583}{81,896+82,583+82,583}=0,3343$

Maka Si B masuk di jurusan IIK (Ilmu-ilmu Keagamaan) atau Agama, walaupun antara hasil nilai IPS dan Agama sama tapi pilihan pertamanya adalah IIK (Agama).

- Hasil si C

Proses Perhitungan menentukan jurusan terbaik si $\mathrm{C}$ adalah sebagai berikut :

$$
\begin{aligned}
& \text { Vmia Si C }=\frac{74,591}{74,591+75,597+74,788}=0,3316 \\
& \text { Viis Si C }=\frac{75,597}{74,591+75,597+74,788}=0,3360 \\
& \text { Viik Si C }=\frac{74,788}{74,591+75,597+74,788}=0,3324
\end{aligned}
$$

Maka Si C masuk di jurusan IIS (Ilmu-Ilmu Sosial) atau IPS, karena pilihan pertama adalah IIS (IPS).

- Hasil si D

Proses Perhitungan menentukan jurusan terbaik si D adalah sebagai berikut :

$$
\begin{aligned}
& \text { Vmia Si D }=\frac{77,062}{77,062+77,494+82,504}=0,3251 \\
& \text { Viis Si D }=\frac{77,494}{77,062+77,494+82,504}=0,3269 \\
& \text { Viik Si D }=\frac{82,504}{77,062+77,494+82,504}=0,3480
\end{aligned}
$$

Maka Si D masuk di jurusan IIK (Ilmu-Ilmu Keagamaan) atau Agama, karena prioritas pemilihan terdapat pada penyeleksian berdasarkan jurusan yang di sarankan, walaupun pilihan pertama yaitu IPS. Walaupun di Jurusan IIS (IPS) masih terpenuhi daya tampung, namun disarankan untuk masuk jurusan IIK karena nilai perhitungannya menunjukkan nilai tertinggi berada di jurusan IIK (AGAMA).

\subsection{Perhitungan Penerimaan secara sederhana}

Dalam perhitungan ini hanya melakukan perhitungan dengan dikalikan pembobotan yang sudah di diskusikan dengan pihak sekolah terlebih dahulu yaitu untuk nilai rapor dan psikotes sebesar $20 \%$, nilai tes akademik dan nilai BTA sebesar $30 \%$, yang nantinya untuk mempertimbangkan dan menentukan status diterima atau tidaknya pendaftar menjadi peserta didik baru di perankingan jurusan masingmasing. Adapun perhitungan sebagai berikut :

\subsubsection{Penilaian Rapor}

TABEL 10

PENILAIAN RAPOR

\begin{tabular}{|c|c|l|l|l|l|l|l|l|c|}
\hline \multirow{2}{*}{ No } & \multirow{2}{*}{ Nama } & \multicolumn{6}{|c|}{ Nilai Rapor 20\% } & \multirow{2}{*}{$\begin{array}{c}\text { Rata } \\
\text { Rapor }\end{array}$} & \multirow{2}{*}{ Jumlah } \\
\cline { 3 - 8 } & & IPA & IPS & Ag & BI & B.Ing & MTK & \\
\hline 1. & si A & 80 & 77 & 78 & 65 & 65 & 70 & 72.50 & 14.50 \\
\hline 2. & si B & 87 & 87 & 87 & 65 & 54 & 80 & 76.67 & 15.33 \\
\hline 3. & si C & 77 & 76 & 65 & 76 & 67 & 79 & 73.33 & 14.67 \\
\hline 4. & si D & 78 & 76 & 89 & 87 & 87 & 88 & 84.17 & 16.83 \\
\hline
\end{tabular}

Pada Tabel 10 Penilaian Rapor ini, rata-rata nilai IPA,IPS,Agama,Bahasa Indonesia, dan Bahasa Inggris dari semester 1 sampai 5 di rata-rata kan seluruh nilainya kemudian dikalikan sebesar $20 \%$. 


\subsubsection{Penilaian Tes Akademik}

TABEL 11

\begin{tabular}{|c|c|c|c|c|c|c|}
\hline \multirow{2}{*}{ No. } & \multirow{2}{*}{ Nama } & \multicolumn{2}{|c|}{ Nilai Tes Akademik 30\% } & \multirow{2}{*}{ Rata TA } & \multirow{2}{*}{ Jumlah } \\
\cline { 3 - 5 } & & IPA & IPS & AGAMA & & \\
\hline 1. & Si A & 80 & 80 & 80 & 80.00 & 24.00 \\
\hline 2, & Si B & 78 & 80 & 80 & 79.33 & 23.80 \\
\hline 3, & Si C & 76 & 80 & 88 & 81.33 & 24.40 \\
\hline 4. & Si D & 77 & 80 & 85 & 80.67 & 24.20 \\
\hline
\end{tabular}

Pada Tabel 11 Penilaian Tes Akademik ini, nilai tes IPA, IPS dan AGAMA di rata-rata kan seluruh nilainya kemudian dikalikan sebesar $30 \%$.

\subsubsection{Penilaian Tes Psikotes}

TABEL 12

Penilaian Tes PSiKotes

\begin{tabular}{|c|c|c|c|}
\hline No. & Nama & Psikotes $20 \%$ & Jumlah \\
\hline 1. & Si A & 77 & 15.4 \\
\hline 2, & Si B & 87 & 17.4 \\
\hline 3, & Si C & 76 & 15.2 \\
\hline 4. & Si D & 75 & 15 \\
\hline
\end{tabular}

Pada Tabel 12 Penilaian Tes Psikotes dikalikan sebesar $20 \%$.

\subsubsection{Penilaian Tes BTA}

TABEL 13

PENILAIAN TES BTA

\begin{tabular}{|c|c|c|c|}
\hline No. & Nama & BTA 30\% & Jumlah \\
\hline 1. & Si A & 67 & 20.1 \\
\hline 2. & Si B & 77 & 23.1 \\
\hline 3. & Si C & 68 & 20.4 \\
\hline 4. & Si D & 78 & 23.4 \\
\hline
\end{tabular}

Pada Tabel 13 Penilaian BTA, untuk nilai BTA (Baca Tulis Al Qur'an) dikalikan sebesar $30 \%$.

\subsubsection{Total Akhir}

TABEL 14
\begin{tabular}{|c|c|c|}
\multicolumn{2}{c}{ TOTAL AKHIR } \\
\hline No. & Nama & Total Akhir \\
\hline 1. & Si B & 79,63 \\
\hline 2. & Si D & 79.43 \\
\hline 3. & Si C & 74.67 \\
\hline 4. & Si A & 74.00 \\
\hline
\end{tabular}

Pada Tabel 14 menerangkan total akhirnya dengan di jumlahkan secara keseluruhan nilai yang telah dikalikan dengan bobot yang telah ditentukan sebelumnya, sistem untuk penerimaan ini adalah sistem gugur, yang mana nanti dicari nilai yang tertinggi sesuai dengan kuota yang di tampung sekolah berdasarkan jurusan Peserta didik ditempatkan.

\subsection{Analisa Kebutuhan Sistem}

Tahapan yang harus dilakukan dalam pengembangan sistem ini adalah :

a. Pengumpulan Data

Mengumpulkan kebutuhan secara lengkap seperti telah dilakukan wawancara kepada Pihak Sekolah mengenai rancangan sistemnya kemudian dianalisis dan didefinisikan kebutuhan yang harus dipenuhi oleh software yang akan dibangun.

b. Menentukan Kebutuhan Fungsional Sistem

Kebutuhan fungsional yang diperlukan oleh sistem ini adalah sebagai berikut :

1. Admin dapat menampilkan informasi dan formulir penerimaan peserta didik baru pada sistem yang dirancang. 
2. Calon Peserta dapat melakukan registrasi pada form formulir di sistem yang dirancang.

3. Admin dapat memasukkan username dan password pada login form di sistem yang dirancang.

4. Admin dapat menambah, mengedit, dan menghapus informasi sistem.

5. Admin dapat menambah, mengedit, dan menghapus, dan mengecek data calon Peserta didik.

6. Admin dapat menambah, mengedit, dan menghapus data kouta kelas

7. Admin dapat menambah, mengedit, dan menghapus data jurusan.

8. Admin dapat menambah, mengedit, dan menghapus data pendidikan.

9. Admin dapat menambah, mengedit, dan menghapus data pekerjaan.

10. Admin dapat menambah, mengedit data nilai mapel pada form formulir di sistem yang dirancang.

11. Admin dapat menambah, mengedit data nilai tes pada form formulir di sistem yang dirancang.

12. Admin dapat menampilkan hasil seleksi pada sistem yang dirancang.

c. Pemodelan Proses

Adapun pemodelan proses dalam sistem ini adalah sebagai berikut :
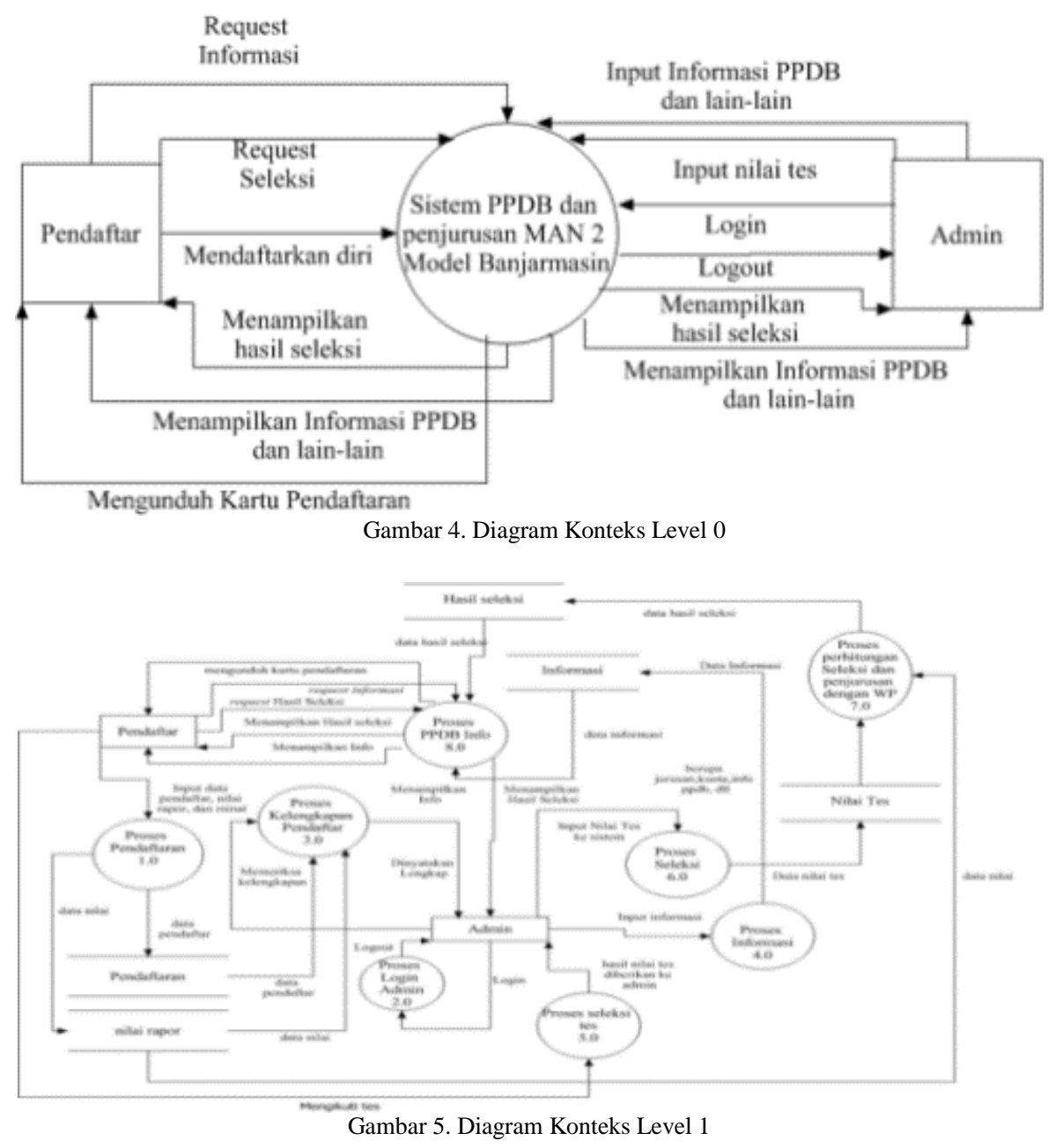

- Admin

Admin akan mengelola semua data antara lain data pendaftar, data jurusan, data kuota kelas, data pendidikan, data pekerjaan, data nilai akademik, data nilai tes, data pengguna, dan data posting. Selain itu juga dapat membuka dan menutup form pendaftaran dan form hasil seleksi di bagian frontend website.

- Pendaftar

Pendaftar hanya dapat melihat informasi penerimaan dan penjurusan, dapat mendaftar langsung tanpa login, dapat mengunduh kartu pendaftaran langsung dan dapat melihat hasil seleksi dengan memasukkan nomor pendaftaran. 


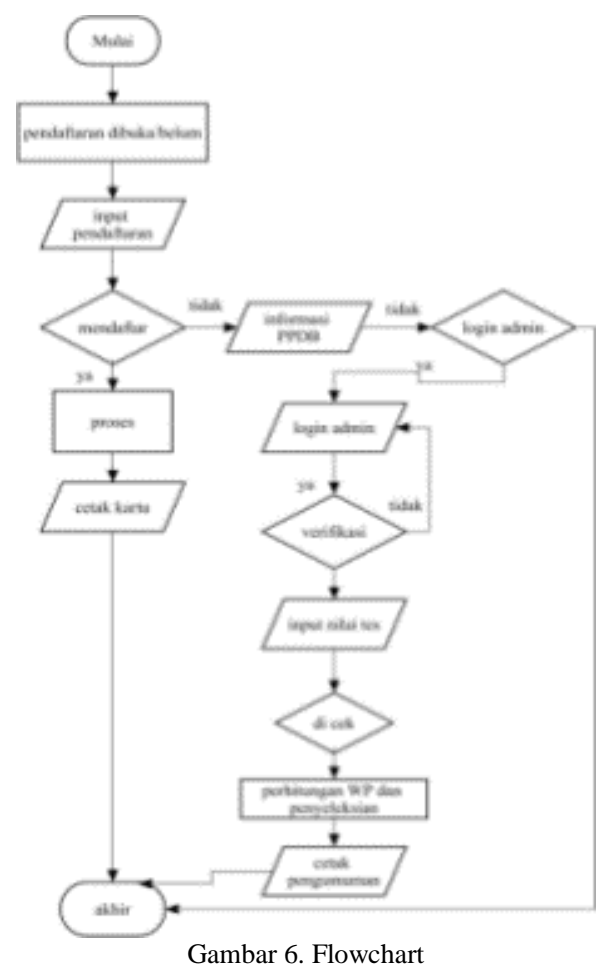

d. Pemodelan Data

Adapun konsep data dalam sistem ini adalah sebagai berikut :

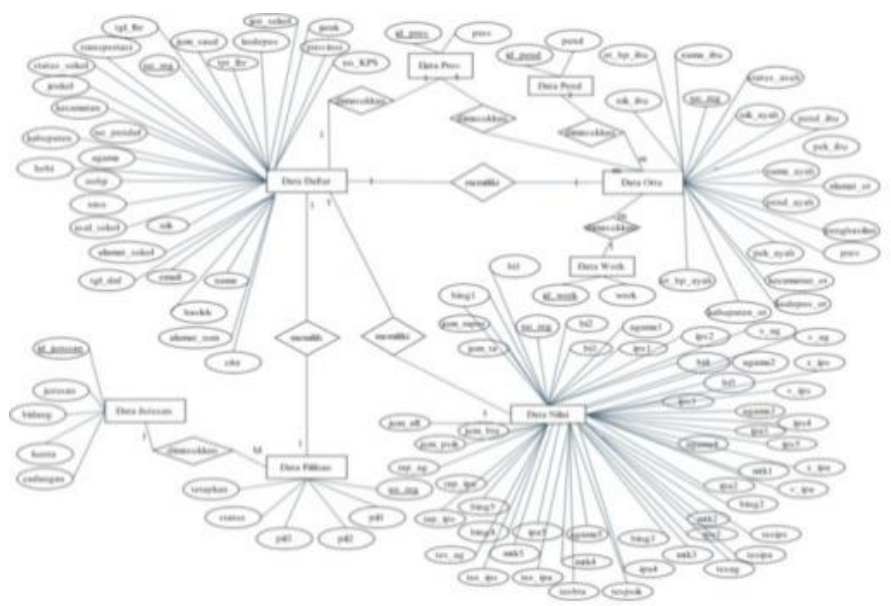

2.5 Kebutuhan Sistem

Gambar 7. ERD

Pada subbab ini dipaparkan implementasi kebutuhan sistem penjurusan dan penerimaan peserta didik baru yaitu sebagai berikut :

- Sistem menggunakan aplikasi browser untuk bisa dijalankan karena berbasis web.

- Sistem ini memiliki rancangan user interface for frontend untuk pendaftar dan user interface for backend untuk Admin.

- Software yang digunakan berbasis php dengan menggunakan framework code igniter dan MySQL.

\section{HASIL DAN PEMBAHASAN}

Dalam pengujian sistem pakar diperlukan presisi dan recall untuk menjadi bahan perbandingan apakah sistem yang dirancang efektif atau tidak efektif. Berdasarkan pengertiannya menyatakan bahwa Presisi adalah perbandingan jumlah dokumen yang relevan terhadap query dengan jumlah dokumen yang terambil sesuai dari hasil pencarian, sedangkan Recall adalah perbandingan jumlah dokumen 
relevan yang terambil dengan query yang diberikan dengan total kumpulan dokumen yang relevan dengan query [6].

Menurut teori Lancaster menjelaskan dalam pencarian presisi dan recall dengan rumus seperti ini.

$$
\begin{gathered}
\text { Presisi }=\frac{\text { jumlah dokumen yang relevan yang terpang gil }}{\text { jumlah dokumen yang terpang gil dalam pencarian }} \times 100 \% \\
\text { Recall }=\frac{\text { jumlah dokumen yang relevan yang terpangil }}{\text { jumlah dokumen yang relevan yang ada di dalam database }} \times 100 \%
\end{gathered}
$$

Jadi, pada 40 data sampel pendaftar menunjukkan bahwa data yang ditetapkan sesuai disarankan sistem dan berstatus diterima yaitu sebesar 26 data sampel dari 30 data sampel yang berstatus diterima, dan 4 data sampel pendaftar lainnya berstatus diterima namun tidak sesuai dengan ketetapan yang disarankan oleh sistem ini. Oleh karena itu dapat dihitung hasil uji presisi dan recall sesuai dengan perhitungan sebagai berikut :

$$
\begin{aligned}
& \operatorname{Presisi}(\%)=\frac{26}{30} \times 100 \%=86,66 \% \\
& \operatorname{Recall}(\%)=\frac{26}{40} \times 100 \%=65,00 \%
\end{aligned}
$$

Berdasarkan teori Lancaster yaitu relevan dan tidak relevan. Dalam teori tersebut juga dijelaskan bahwa efektifitas sistem temu kembali informasi dikategorikan menjadi dua yaitu efektif jika nilainya diatas $50 \%$ dan tidak efektif jika nilainya dibawah $50 \%$. Kedua ukuran diatas dinilai dalam bentuk presentase 1-100\% [7]. Oleh karena itu, tingkat keefektifan dari Sistem temu kembali penjurusan dan penerimaan peserta didik baru tersebut sudah dikatakan efektif, karena efektifitas sistem menunjukkan diatas $50 \%$.

\section{KESIMPULAN}

Dengan adanya Sistem Penerimaan Peserta Didik dan Penjurusan Menggunakan Metode Weighted Product di MAN 2 Model Banjarmasin ini, maka Penulis dapat mengambil kesimpulan bahwa dalam merancang dan membangun Sistem Penjurusan dan Penerimaan Peserta Didik Baru Menggunakan Metode Weighted Product di MAN 2 Model Banjarmasin ini dengan melakukan pengujian presisi dan recall, mendapatkan hasil nilai pengujian yaitu nilai presisi sebesar $86,66 \%$ dan nilai recall sebesar $65,00 \%$, hal ini menunjukkan bahwa nilai presisi lebih besar daripada nilai recall, namun dalam tingkat efektifitas sistem temu kembali penjurusan dan penerimaan peserta didik ini sudah dapat dikatakan efektif karena menunjukkan nilai diatas 50\% dari perhitungan persentase 1-100\%.

Sistem Informasi Penjurusan dan Penerimaan Peserta Didik Baru Menggunakan Metode Weighted Product ini dapat diakses dari semua internet browser untuk melakukan pendaftaran online dan melihat berbagai informasi tentang PPDB di MAN 2 Model Banjarmasin, tetapi dibalik itu semua, masih perlu perbaikan dan pengembangan lagi pada sistem ini, karena sangat terbatasnya waktu yang tersedia, yaitu sebagai berikut :

1. Perlunya meningkatan efektifitas Sistem Penjurusan dan Penerimaan Peserta Didik Baru MAN 2 Model Banjarmasin.

2. Perlunya pembaharuan sistem dalam membuat button yang dapat satu kali klik langsung menyimpan semua data Pendaftar pada penjurusan dan penyeleksian.

\section{DAFTAR PUSTAKA}

[1] Kemenag. (2017). Pedoman Penerimaan Peserta Didik Baru Tahun 2017-2018. Jakarta: Kementerian Agama.

[2] Permendikbud. (2014). Peraturan Menteri Pendidikan dan Kebudayaan RI No 64 tentang Peminatan pada Pendidikan Menengah. Jakarta: Mendikbud.

[3] Liang, T. A. (2005). Decision Support System and Intelligent System 7th Edition. New Delhi: Prentice'Hall of India.

[4] Basyaib, F. (2009). Teori Pembuatan Keputusan. Jakarta: PT Grasindo.

[5] Sianturi, Ingot Seen. (2013). Sistem Pendukung Keputusan untuk Menentukan Pemilihan Jurusan Siswa dengan Menggunakan Metode Weighted Product (WP) (Studi Kasus : SMA SWASTA HKBP DOLOKSANGGUL). Informasi dan Teknologi Ilmiah (INTI), Volume :1

[6] Kurniawan,D. (2010). Evaluasi Sistem temu kembali informasi model ruang vector dengan pendekatan user judgement, Jurusan Matematika Program Studi Ilmu Komputer FMIPA Universitas Lampung. Lampung: Universitas Lampung.

[7] Pendit, PL. (2008). Perpustakaan Digital dari A sampai Z. Jakarta: Cita Karyakarsa Mandiri. 
[8] Fauzan, R., Siahaan, D., O., Ariyani, N., F. (2013). Rekomendasi Kasus Penggunaan Berdasarkan Skenario Naratif Menggunakan Teknologi Semantik. JUTI: Jurnal Ilmiah Teknologi Informasi, Jilid 11, Hal 34-39.

[9] Fauzan,R., Syaripah. (2016). Sistem Prediksi Jumlah Produksi Padi Pada Kabupaten Barito Kuala Dengan Menggunakan Metode KNearestneighbor (Knn). Phasti, Volume 2, No 1, Hal 24-31.

[10] Fitri, R,. Asyikin, A., N. (2015). Aplikasi Penilaian Ujian Essay Otomatis Menggunakan Metode Cosine Similarity. Jurnal POROS TEKNIK, Volume 7, Hal 88-94. 